\title{
Urgency of Political Decentralization and Regional Autonomy in Indonesia: Local Perspectives
}

\author{
${ }^{1}$ Andi Yakub, ${ }^{2}$ Ahmad Bashawir Abdul Ghani \& ${ }^{3}$ Mohammad Syafi'i Anwar \\ ${ }^{1 \& 2}$ Hasanuddin University, Indonesia \\ ${ }^{2 \& 3}$ School of International Studies, Universiti Utara Malaysia \\ Corresponding author: andyakub@gmail.com \\ DOI: https://doi.org/10.32890/jis2018.14.9 \\ Received: 4 January 2018 \\ Revised: 28 November 2018
}

Accepted: 8 December 2018

\begin{abstract}
Indonesia is a country that is inhabited by hundreds of ethnic groups with different geographical condition, natural resources and social culture. Regional decentralization and autonomy that is carried out in Indonesia is an acknowledgment of ethnic diversity (pluralism) to create unity and harmony (BhinekaTunggal Ika), to form social harmony and equal development with the framework of protecting national stability. This article argues on the urgency of political decentralization and regional autonomy in Indonesia through local perspectives by using political decentralization/local democracy model approach with the centrifugal style of authority and government decentralization and structural efficiency model approach with centripetal style.
\end{abstract}

Keywords: Decentralization; Bhineka Tunggal Ika; social harmony; national stability; local value; local wisdom; social justice.

\section{Introduction}

Political decentralization has been the preferred policy for various developing countries. The idea that political decentralization being an instrument that could form an effective, efficient, responsible and accountable administration has become a strong stimulant for many countries to adopt. Nevertheless, in terms of theoretical or empirical, political decentralization still becomes pro-contra; whether it has positive or negative values. Also, decentralization concept itself is often partially instead of holistically apprehended. Nonetheless in terms of principle, there are emergencies of various responses regarding the idea of political decentralization being derived from centralist political system structure. In other words, this is due to centralist political structure being inclined towards uniformity/ centralization (centripetal) of political power in the hand of central government whereas decentralization proposed an idea about uniformity or spreading (centrifugal) of power and authority between central and regional government. Therefore, what is actually is the urgency of political decentralization? 
Various thoughts regarding political decentralization and regional autonomy show that the issue regarding said policies are highly related to empowerment, which means giving power and authority to regional community to initiate and makes decision in managing the community's interests. The manifestation of empowerment will enable the local government institution and the community to have access not only towards decision making at regional level but also have access towards decision making at central level that is related to the people and regional interest.

This article will argue on the urgency of political decentralization and regional autonomy in Indonesia through local perspectives. These perspectives will be in terms of treatment of diversity, strengthening of unity, protection of national stability, social harmonization, while still maintaining relationship between central and regional government equally by advancing towards development from outskirts policy to establish social justice for local community.

Approach in the Study on Decentralization. In this study on decentralization, there are two main courses of approaches are i) political decentralization/local democracy model approach with centrifugal style of authority, and ii) government decentralization/structural efficiency model approach with centripetal style of authority.

\section{Political Decentralization/Local Democracy Model Approach}

The local democracy model originated from the theory of a regional government that was developed based on political theories, Hambleton, (1994). Local democracy model according to Stoker, (1990, 2017) has a number of values. Firstly, a regional government that is based on trust has its value in terms of spreading of power and involvement of various decision makers at regional level. Secondly, its views about the strength in diversity is responsive towards diversity of interests. Thirdly, local based regional government that facilitates access and responsive towards local community due to the administration being close to the local community. Fourthly, the spreading of power is a fundamental value and regional government that consists of an election based institution will be able to represent spreading (centrifugal) of valid political power among local community.

Fact regarding political decentralization and regional autonomy policy that is served in $U U$ No. 22 Years 1999 related to $U U$ No. 32 two Years 2004 related to $U U$ No. 23 Years 2014 about regional government, held high democracy principle and society diversity in maintaining political decentralization in addition, the article 18 UUD 1945 includes constitutional base; division of regions in Indonesia according to large and small regions with the structure of administration stipulated by law, by viewing and remembering consultation policy in national administration system, and special origin rights of the regions. The statement "Consultation policy in National Administration System" contains the meaning of our democracy, with belief that in a limited condition, decentralization of democratization 
undoubtedly has context-specific quality and continuation of decentralization democracy is determined by the people that fight for national transformation. The continuation of decentralization of democratization process will not be easily submitted to the state or authority (Santoso, 2018).

\section{Decentralization Government/Structural Efficiency Model Approach}

Structural efficiency model originated came from the theory of a regional government from a based on management theory. The regional government structure that was established from regional government model embraced by Act No. 5 Years 1974 was theoretically called structural efficiency model. This model highlights on the importance of efficient service distribution towards the local community in accomplishing political decentralization. In order to create uniformity and conformity of efficient and economic service mechanism, this model encourages the involvement of higher power ruler to provide control towards local government (Aulich, 1998).

Generally, structural efficiency model embraces priority scaling. The purpose of political decentralization is to create efficient administration in a united nation system. In a country, there are groups embracing structural efficiency model with priority scaling, through purpose of decentralization which is efficient and seek for a united nation that has centrifugal style of authority (Cheema \& Rondinelli, 1993).

First, there is a tendency to cut a number of regional autonomy structures. Second, there is tendency to sacrifice democracy by limiting the roles and participation of the local people 's representative as policy maker and control institutions. Third, there is a tendency for central government to refuse passing the power and discretion to local government. Fourth, tendency in prioritizing de-concentration over decentralization. Fifth, the occurrence of paradox: from one perspective, efficiency requires a region that has a wide autonomous power to provide natural resources that could support the circle of regional administration. However, from another perspective, a region with wide autonomous power is feared to have potentiality to experience separatist movements. Hence, to reduce the structure of regional autonomy, regional autonomy with wide region becomes the main target to be liquidated. These tendencies occur within the time frame of Act No. 5 Years 1974. Nevertheless, its actual empirical effect is still sensed nowadays.

\section{What Is the Urgency of Political Decentralization and Regional Autonomy?}

Generally, urgency of political decentralization can be differentiated based on the researcher's point of view. Some of researchers perceived it from political, economic, macro-micro, and even socio-culture development perspectives. 
Political decentralization in terms of economical dimension is to amplify the ability of local government in providing public good and services, as well as enhancing the efficiency and effectiveness of economic development in a region, Rondinelli (1983), Nordholt, (2007). This view implies that political decentralization functioned as an instrument to widen public space for people who make choices on public goods and services where would eventually towards contribute existence of balancing between individual rights and collective harmony. Aligned with Ruland, (1992), Hidayat, (2007), political decentralization where consequent will necessarily release regional autonomy necessity as it will increase people political participation in turn to support development of social, economy and political aspects.

Thus, Kimlicka $(1995,2002)$ mentioned that there are six main aspects related to principal value of political decentralization urgency. Those are: (i) Trust towards equality and justice, (ii) Trust towards consultation and dialogue, (iii) Importance of adaptation and toleration, (iv) Participation in unity in diversity, (v) Empathy, which is love and generosity, commitment towards freedom and peace, and (vi) Changes without violence.

Moreover, according to Smith (1995), political decentralization from macro aspect or the aspect of importance central government has three urgencies' which are: (i) Political education, (ii) Leadership training, and (iii) Forming of political stability. In micro or regional importance, those three urgencies are: (i) Political decentralization, ii) Local government's responsibility towards the people, and (iii) Response from the local government towards various concerns.

According to Briant \& White (1989), political decentralization and regional autonomy are related to social development aspect knowing as "the ability to increase the humans' capability to influence their future" with the main implication (capacity, justice, empowerment, sustainability, freedom and local independence).

Growing interest towards decentralization shows that political decentralization and administration decentralization are not only a signs of acknowledgment of the weakness in the design of central administration but a shift in policy that emphasizes on growth strategy that is accompanied by equalization strategy. Furthermore, it is generally recognized that development is a complex and uncertain process that is not easy to be carried out and handled from its foundation. The coexistence of a full political decentralization and a regional autonomy that is set loose from central authority of central government is impossible. However according to who similarity and unity in opinion about the necessity of decentralization and regional autonomy. Mohammad Hatta raised his opinion in the statement in Hoessein, (2001), Pane, (2015), raise his opinion about political decentralization and regional autonomy:

“... Granting regional autonomy does not mean implementation of democracy, but encouraging the growth of auto-activiteit. Auto-activiteit means moving alone, selfexecuting what is deemed important within one's surrounding. With the growth of auto- 
activiteit, what is meant by democracy will be achieved that is governing by the people and for the people. The people not only determine their destiny, but improve their destiny". (Speech Hatta, 1957).

The content of speech, proposal, and debate of Indonesian founding fathers emphasize that they were viewing political decentralization in Indonesia as a fundament that could be accepted. In the end, they concluded that a decentralized united nation system is the most suitable state system for people of Indonesia that are diverse in terms of geography, tribe, religion, ethnicity, and groups (political, economic and cultural interests).

The different thoughts mentioned concluded that a more decentralized autonomy system benefits in terms of (i) Wider chance of equal distribution of power among local communities, (ii) better inclusiveness of society's political education, (iii) stronger stability of political system, and (iv) closencess of the nation to its people. To sum up, local people would enjoy a wide opportunity to drive their own region based on their objective condition.

\section{Urgency of Political Decentralization and Regional Autonomy in Indonesia}

Based on various thoughts that were explained above, it can be summarized that the urgency of political decentralization and regional autonomy in Indonesia concists of: (i) Pluralism (diversity of communities in living in unity), (ii) Acknowledgment and respect towards the principle of nation, state, government and community well and dynamic political stability as well as national integration and harmonisation between central government and local government is achieved, and (iii) Development from the outskirts in the aproach "from regional to Indonesia" Santoso, (2018). According to create development equality to empower and enhance the regional ability observing the condition/characteristics of region (local wisdom) such as in Bugis community, Siri na Pesse (pride and empathy) that is created in Bugisness local values; honouring each other (sipakatau), cherishing each other (sipakalebbi), and reminding each other (sipakainge). Mattulada (1995), Condition related to different cultural strategies in one archipelago vision of Republic of Indonesia explained as follow:

\section{The Bhineka Tunggal Ika: Create Unity And Harmony}

Fundamentally, the issues that emerged in the process of national unity were due to the occurrence of tensions in power structure that was caused by the establishment of a nation state. Therefore, national unity involves sovereignty issue, especially related to the process of power shifting within community groups and the process of dividing, using and distributing power among them. From the authority perspective, national unity basically is composed of two main issues which are: (i) Ways to ensure that people, (ii) ways to 
increase tnormative/concessional consensus that arrange the community's political attitude or participating individual.

In order to curb these issues within a heterogeneous community, proposed two strategies. First, is assimilation. Second, is unity in diversity (in Indonesia it called as Bhineka Tunggal $I \mathrm{ka}$ ). Assimilation is the achievement of national unity by appointing the dominant ethnic culture in a country as national culture. This method can be accomplished by subjugating the ideas of entities or minority group into dominant cultural ethnic (Weiner, 1994).

Besides, Bhineka Tunggal Ika strategy is defined as an effort to create national loyalty without vanquishing the minority groups' culture. Unity in diversity strategy or Bhineka Tunggal Ika is widely viewed as an accentuation on unity (tunggal ika) without sacrificing diversity (bhinneka). Many Bugis local elites believed that in practice, unity has become a central part of hegemonic discourse of the new order era, and nullified acknowledgement regarding the need of socio-cultural diversity (pluralism) in the form of local wisdom among people of Indonesia until the reformation order regime.

\section{National Stability: Arrangement of Central and Regional Relationship}

The relation between central and regional relationship stresses on equalization in development and its sources, together with healthy and dynamic economic growth and political stability. In studying central and regional relationship in Indonesia, various points are found that would encourage fragmentation instead of unity. Indonesia has an area that almost covers 4.8 million $\mathrm{km} 2$ of which 1.9 million $\mathrm{km} 2$ are comprised of scattered lands (13 667 islands that stretch from $5110 \mathrm{~km}$ from east to west and 1880 from north to south) where have facilitate of various prominent Bhinneka or diversity (BPS, 2017).

Based on social perspective, Indonesia is a country that has been marked by many contrasting issues. For the regional people, central people (Java) is the socially dominant group that tends to viewed as the representative of Indonesia. Nonetheless, it is a fact where 300 ethnic groups that are widely spread all over Indonesia considering its geographical location as an archipelago. Being Indonesia an archipelago, it geographical confirmation has become an obstacle for the development of the communication between various different regions that is deemed vital to end the existing isolation and bridge differences. Just after the new order extended the highway system, the sea navigation and air navigation to all regions that communication becomes smoother and regional isolation is curbed.

Economically, Java depends on the regions outside of Java that count almost $50 \%$ of Gross Domestic Product (GDP). Thus, regions outside of Java such as Kalimantan, Sulawesi and Papua are rich with natural resources such as gold mines, nickels, coals, cements, rattan and other materials which constitute Indonesia's main export products (BPS, 2017). Profit gained from outside of Java Island region is directly channelled to Jakarta that causes 
disappointment of the regions towards central in the past. It moreover caused inequality between Java and the outsiders.

Due to that policy, it was not unusual that a number of changes in the pattern of relationship between central and regional occurred throughout Indonesia's history. Nevertheless, there is one condition that never changed since the beginning, which is the domination of Java; central government is given centrifugal power in terms of political and administrative authority.

Many claimed related the unfair relationship condition between the central government and the regional were unaccepted. They viewed this inequality as one of the factors that enable forming Indonesian people's disintegration. It was believed that the central government was receiving a disproportionate portion of "kue pembangunan nasional" or "the national development benefit sharing". then seen as important aspect of the rampant of collusion, corruption, and nepotism in central as well as in the regional level. That condition spreads discontentment in the regions including South Sulawesi. Unfair development between eastern Indonesia and western Indonesia or centre-periphery is regarded as a source of threat towards national integration.

The fact that althoght many provinces are rich with natural resources, but are still poor is the cause for local community's resistance and many criticisms towards central government. Over centralization is regarded as the cause of unawareness and nonempathetic approach by the central government and creates a sense of isolation in local community in regard to development.

\section{Development from Outskirts: Political Decentralization and Regional Autonomy Policy}

Issues regarding the domination of the central government or usually called as "Jakarta" as the name of Indonesia capital city remain fundamental by the regions. The issues mentioned will the discussion of urgency of political decentralization and regional autonomy policy in Indonesia.

In developing countries, the dilemma regarding centralization and decentralization is a prominent issue particularly related to efficient utilization of limited natural resources. Centralization and decentralization topic leads to discussion about the excavation of natural resources and returned distribution and allocation of natural resources and extracting capability. The phenomenon in which a region which is rich in natural resources and contributes the most to the national economy by actually gaining the least allocation of economic asset causes discontentment. It then tends to lead some separatism movement erupted such as the Aceh Freedom Movement of "Gerakan Aceh Merdeka") GAM or the Freedom Papua Organization "Organisasi Papua Merdeka" (OPM). Some of these 
movements were meant to demand for autonomy or even independent from the Indonesia central government where lead the issue of more democratic decentralization.

In Indonesia discourse about decentralization and regional autonomy becomes prominent when the execution of economic development that is implemented by new order regime encounters problem. It causes formation of structure inequality between sectors or between regions. The occurrence of the inequality pattern in the future could be a strong back wash in order to continue the development of nation.

Besides, re-emergence of political decentralization and regional autonomy policy means that the central government cannot escape from reduction of fund whether from crude oil or foreign revenue (export products). The reduction of crude oil income and foreign revenue causes the shifting in the structure of state revenue as well as increase in tax revenue as a force and stabilizer of economic growth. This tendency has been happening throughout the years within the government whether in central Jakarta or local government outside of Java Island. Autonomy is perceived solely from economic perception that is in terms of its efficiency and effective.

At the same time, there is "phobia" towards past political decentralization that failed to observe democratization and political dynamic aspects of the local community and regional government that would occur. This might be due to the strong effect of planned paradigm development that has central characteristic (top down) as long as the central government believes that they are fully responsible towards national development. In terms of finance, it is clear the region is at the end position and is very dependent while dynamic regional development is difficult to be performed without sufficient fund (presence of fiscal decentralization). Local government becomes slow in handling problems that arise in their region such as poverty, city-country inequality, and small locally-generated revenue as they are ripped of all attributes of regional autonomy in Indonesia as political decentralization.

Hence, in order to create economic justice or economic democracy, Mubyarto, $(1988,1990)$ stated that the ethical rules of games must be obeyed in economic relationship. In regard to relationship of central government and regional people, economic justice must become the moral foundation in which the central government must make effort to understand and fulfil it. According to Perlas (2006) that the strengthening of regional economic structure that is based on local wisdom; Bugis community is known for the concept mutual cooperation and help (malii siparappe, rebba sipatokkong) and a national economic system that is not too centralistic. This clearly will lift up the region government and its people to be more active and less dependent on central power in the form of "cooperation" which means economic democracy. Economic democracy will exist by expanding decentralization and regional autonomy. Regions that have high potential must quickly achieve independence in organizing regional finance (fiscal decentralization) so that economic, politics and social gap can be overcome at its own region as well as reducing poverty and dependency towards central with the designation of development from outskirts: from region to Indonesia, with the intention to create social justice for local community (Yakub, et al., 2018). 


\section{Conclusion}

Urgency of political decentralization and regional autonomy is hoped to create: (i) efficiency and effectiveness of government management that leads to public harmony, (ii) regional administration that is responsible in various aspects of local community's life, (iii) local government that is responsive towards various issues that are encountered by local community, and (iv) an increase role of community in democracy administration process as in there is an opening for the people to participate in various political activities at the local level. Therefore, political decentralization must be able to enhance the welfare and quality of life of the local community. This can be accomplished by preserving Bhineka Tunggal Ika, protect national stability, strengthen local community based on local wisdom and local values, and move forward towards the policy of development from outskirts: from region to Indonesia, with the framework to create social justice for local community.

\section{References}

Aulich, C. (1999). Reforming Australian Government: Intact and implication for local public administration. In Political management in Australian Local Government.

Badan Pusat Statistik (BPS). (2017). Indikator makro sosial ekonomi Sulawesi Selatan. Triwulan I. Press.

Bryant, C., \& White, L. G. (1989). Manajemen pembangunan untuk negara berkembang. Jakarta: LP3ES.

Cheema G. S., \& Rondinelli, D. A. (1983). Decentralization and development policy implementation in developing countries. Beverly Hills/London/New Delhi. Sage Publication.

Fukuyama, F. (2005). Memperkuat negara: Tata pemerintahan dan tata dunia abad 21. Jakarta: Fredom Institute dan Gramedia Pustaka Utama.

Hambelton, R. (1994). The politics of decentralization, revitalising local democracy. London: MacMilan.

Hidayat, S. (2007). Too much too soon: Local state elite's perspective on and the puzzle of contemporarey Indonesian regional autonomy policy. Jakarta: PT Raja Grafindo Persada.

Hoessein. B. (2001). Reformasi pemerintahan daerah di Indonesia. Jurnal Ilmu Sosial dan Ilmu Politik: Otonomi Daerah Masalah dan Prospek, 3(2), 19-28. Jakarta: JISIP Universitas Nasional.

Kymlicka, W. (1995). Multicultural citizenship: A liberal theory of minority right. New York: Oxford University Press.

Kymlicka, W. (2002). Kewargaan multikultural. Jakarta: LP3ES.

Maddick, H. (2004). Desentralisasi dalam praktek. Yogyakarta: Pustaka Kendi.

Mattulada. (1995). Latoa: Suatu lukisan analisis terhadap antropologi politik orang Bugis. Ujung Pandang: Hasanuddin University Press.

Mubyarto. (1988). Sistem dan moral ekonomi Pancasila. Bandung: LP3ES. 
Mubyarto, \& Boediono. (1990). Ekonomi Pancasila. Yogyakarta: BPFE Yogyakarta.

Nordholt, H. S., \& Gerry, V. K. (2007). Politik lokal di Indonesia. Jakarta: KITLV Dan Yayasan Obor Indonesia.

Pane, N. (2015). Mohammad Hatta: Politik, kebangsaan, ekonomi. Jakarta: PT Kompas Media Nusantara.

Perlas, C. (2006). Manusia Bugis. Jakarta: Penerbit Nalar.

Rondinelli, D. A. (1983). Goverment dezentralization in comparative perspective: Theory and practice in developing countries. International Review of Administrative Sciences, XLVII (2).

Roskin, M. G., Robert, L. C., James, A. M., \& Walter, S. J. (2016). Pengantar ilmu politik. Jakarta: Kencana.

Ruland, J. (1992). Urban development in Southeast Asia: Regional cities and local government. Boulder: Westview Press.

Santoso. P. (2018). Lokalitas sebagai konteks untuk berdemokrasi: Rezim lokal di Indonesia. memaknai ulang demokrasi kita. (39-72). Jakarta. Yayasan Pustaka Obor.

Stoker, G. (2017). Theory and methods in political science. London: Palgrave Macmillan.

Smith, B. C. (1995). Choices in the design of decentralization. London: London Commonwealth Secretariat.

Weiner, M. (1994). Modernisasi: Dinamika pertumbuhan. Yogyakarta: Gadjahmada University Press.

Yakub, A., Bashawir, A., \& Syafi'i, A. (2018). Bugis etnic perception towards urgency of political decentralisation and district authonomy in South Sulawesi, Indonesia. International journal of Multidisciplinary Research and Development, 5 (10), 140145.

Undang-Undang Nomor 5 Tahun 1974 Tentang Pokok-Pokok Pemerintahan di Daerah.

Undang-Undang Nomor 22 Tahun 1999 Tentang Pemerintahan Daerah.

Undang-Undang Nomor 32 Tahun 2004 Tentang Pemerintahan Daerah.

Undang-Undang Nomor 23 Tahun 2014 Tentang Pemerintahan Daereah. 